\title{
Effects of whole body cryotherapy in patients with rheumatoid arthritis considering immune parameters
}

\author{
Teresa Sadura-Sieklucka ${ }^{1}$, Beata Sołtysiuk ${ }^{1}$, Anna Karlicka ${ }^{1}$, Beata Sokołowska ${ }^{2}$, Ewa Kontny ${ }^{3}$, \\ Krystyna Księżopolska-Orłowska ${ }^{4}$
}

${ }^{1}$ Clinic of Rehabilitation, National Institute of Geriatrics, Rheumatology and Rehabilitation, Warsaw, Poland

${ }^{2}$ Mossakowski Medical Research Centre, Polish Academy of Sciences, Warsaw, Poland

${ }^{3}$ Department of Pathophysiology and Immunology, National Institute of Geriatrics, Rheumatology and Rehabilitation, Warsaw, Poland

${ }^{4}$ Consultant in National Institute of Geriatrics, Rheumatology and Rehabilitation, Warsaw, Poland

\begin{abstract}
Objectives: Whole body cryotherapy (WBC) is widely used in inflammatory diseases of the joints, including rheumatoid arthritis (RA), but the mechanism(s) of its action is not fully understood. The aim of the study was to compare the effects of WBC and conventional rehabilitation (CR) on the clinical and immune status of RA patients.

Material and methods: Rheumatoid arthritis patients were classified into 2 groups according to the rehabilitation method used: the study group (CT, $n=25)$ and control group (CR, $n=25)$. To measure disease activity, the disease activity score (DAS28) was used, while to assess the morning stiffness and pain intensity, the visual analogue scale (VAS) was applied. Selected laboratory parameters, such as erythrocyte sedimentation rate (ESR) and C-reactive protein (CRP) levels, were also determined. The serum concentrations of pro- (interleukin 6 [IL-6], tumor necrosis factor $\alpha$ [TNF- $\alpha$ ], macrophage migration inhibitory factor [MIF]) and anti-inflammatory (IL-10) cytokines were measured to assess the patient's immune status.

Results: After rehabilitation disease activity (DAS28), morning stiffness and pain intensity (VAS) decreased in both patient groups and no statistically significant differences were observed between them. However, statistically significant improvement in the CRP serum level was observed in the CT group only. No differences were observed in the serum concentrations of tested cytokines either before and after rehabilitation, or between patient groups.

Conclusions: We report that regardless of the type of therapy, comprehensive rehabilitation improves the patient's clinical status, but has no effect on the levels of circulating cytokines, such as IL-6, IL-10, TNF- $\alpha$, and MIF, despite significant reduction of a systemic inflammatory marker (CRP), especially in the CT group.
\end{abstract}

Key words: rheumatoid arthritis, cytokines, whole body cryotherapy.

\section{Introduction}

Rheumatoid arthritis (RA) is an inflammatory, chronic systemic disease that causes increasing disability as well as premature death. It begins symmetrically in the synovium, leading to the gradual destruction of joints and periarticular structures, which results in deformities. Morning stiffness, pain, swelling, exudations and limita- tion of the range of joint movement as well as weakening of muscle strength are problems that affect patients [1, 2].

Proinflammatory cytokines, such as tumor necrosis factor $\alpha$ (TNF- $\alpha$ ), interleukin 6 (IL-6) and macrophage migration inhibitory factor (MIF), participate in the pathogenesis of RA, and have a negative impact on the course and severity of the disease [3-6]. Interleukin 10, which has anti-inflammatory properties, is not able to counter-

Address for correspondence:

Teresa Sadura-Sieklucka, Clinic of Rehabilitation National Institute of Geriatrics, Rheumatology and Rehabilitation, 1 Spartańska St., 02-637 Warsaw, Poland, e-mail: teresa@sieklucka.com

Submitted: 4.10.2019; Accepted: 22.11.2019 
act the effects of proinflammatory factors, because its body fluid concentrations are usually low [7].

In RA, increasing dysfunction within the musculoskeletal system is the cause of limitations in personal, social and professional life [8]. The main goal of rehabilitation is to reduce the intensity of disease symptoms, as well as improve functioning and thus minimize disability [9].

Improvement is a long-term process and depends on the degree and type of deformation and disease activity [10]. In addition to pharmacotherapy, rehabilitation treatment is a very important element in the management of RA. Benefits resulting from the use of various physiotherapeutic procedures were observed, from the next 4 to 6 months of improvement [11-14]. It is likely that rebalancing of the cytokine network may be associated with clinical improvement observed after rehabilitation.

One of the forms of therapy recommended for inflammatory diseases is systemic cryotherapy. Cryostimulation relies on the use of temperatures below $-100^{\circ} \mathrm{C}$ for about 3 minutes to produce a thermal effect, which reduces pain and increase the range of motion [15]. This method is more effective than other methods of conventional physiotherapy; it reduces pain, improves locomotion and maintains the desire to continue professional work in patients with RA [16].

However, scientific evidence confirming the effectiveness of systemic cryotherapy is still insufficient. Therefore, the study attempts to assess the impact of whole body cryotherapy (WBC) on selected parameters reflecting the patient's clinical and immune status, i.e. disease activity and pain and the concentrations of the circulating pool of pro- and anti-inflammatory cytokines in patients with RA.

\section{Material and methods}

Patients from the Clinic of Rehabilitation at the $\mathrm{Na}$ tional Institute of Geriatrics, Rheumatology and Reha-

Table I. Characteristics of the patient groups $(n=50)$

\begin{tabular}{|lcc|}
\hline Parameters & $\begin{array}{c}\text { Rehabilitation } \\
\text { group (CR) }\end{array}$ & $\begin{array}{c}\text { Cryotherapy } \\
\text { group (CT) }\end{array}$ \\
\cline { 2 - 3 } & $n=25$ & $n=25$ \\
\hline Age (years) & $50.8 \pm 8.3$ & $43.6 \pm 10.1$ \\
\hline Mean \pm SD & 52 & 41 \\
\hline Median & $(27 ; 59)$ & $(18 ; 58)$ \\
\hline (Min; Max) & $17.2 \pm 10.0$ & $15.9 \pm 12.5$ \\
\hline Disease duration (years) & 20 & 12 \\
\hline Mean $\pm S D$ & $(1 ; 33)$ & $(1 ; 46)$ \\
\hline Median & & \\
\hline Min; Max) & & \\
\hline
\end{tabular}

bilitation in Warsaw with diagnosed RA were recruited to the program. Eighty-three patients were qualified for the study, and fifty patients completed the study.

Inclusion criteria comprised: RA diagnosed in accordance with EULAR criteria [17], adult patients aged 18-59, with stable treatment for at least 3 months, expressing a willingness to cooperate.

Exclusion criteria were as follows: history of cancer, surgery in the last 6 months, change of drugs or drug doses in the last 3 months. The study was approved by the Bioethics Committee at the National Institute of Geriatrics, Rheumatology and Rehabilitation in Warsaw.

Patients were subdivided into two groups depending on the rehabilitation method used: a cryotherapy group (CT) and a conventional rehabilitation group (CR). In Table I the patients' characteristics are shown.

In both groups we used comprehensive rehabilitation which depended on the patient's problems. Physical therapy (electrotherapy, ultrasound, magnetic field, laser therapy) and kinesitherapy (unloading exercises, individual exercises, active exercises, and hand exercises) were used. In addition, the CR group performed 30 minutes of exercises in water, and the CT group underwent WBC (vestibule 30 seconds, $-60^{\circ} \mathrm{C}$; main chamber 2-3 minutes from $-120^{\circ} \mathrm{C}$ to $-140^{\circ} \mathrm{C}$ ).

Patients were evaluated twice: before and after completion of the rehabilitation program (20 treatment days). To measure disease activity, the disease activity score (DAS28) index was used, calculated on the basis of the number of painful and swollen joints, as well as the general state of health according to the patient based on a 100-millimeter visual analogue scale (VAS) and erythrocyte sedimentation rate (ESR) according to the accepted formula [18]. To assess the intensity of pain, the VAS was used, in which 0 meant no pain and 10 meant unbearable pain.

Markers of systemic inflammation, i.e. ESR and serum C-reactive protein (CRP) concentration, were also measured, using routine laboratory methods. The concentrations of cytokines in serum were measured in duplicate using specific ELISA kits. The IL-6 ELISA was performed according to our own procedure, using goat polyclonal, neutralizing antibody specific for human IL-6 (R\&D Systems, Minneapolis, MN), and IL- 6 specific rabbit polyclonal antibody (Sigma-Aldrich, St. Louis, MO, USA), as a capture and detection antibody, respectively, followed by horseradish peroxidase-conjugated goat anti-rabbit immunoglobulins, and o-phenylenediamine dihydrochloride (OPD) (both from Sigma) as a substrate. Human recombinant IL-6 (R\&D Systems) was used as a standard.

The evaluations of other factors were done using following commercially available ELISA sets: the DuoSets from R\&D Systems for MIF, and the Ready-Set-Go sets from eBioscience (San Diego, CA, USA) for TNF- $\alpha$ and IL-10. 


\section{Statistical analysis}

Statistical analysis was performed using the STATISTICA 9.0 PL statistical package software. The values are presented as the mean and standard deviation (SD), or the median and range (min; max).

The distribution of variables was non-normal, as stated by the Shapiro-Wilk test. Therefore, to assess the significance of the differences between variables before and after rehabilitation and between CT and CR groups, the Wilcoxon and Mann-Whitney $U$ tests were applied, respectively. The $p$-value $<0.05$ was considered statistically significant.

\section{Results}

\section{Disease activity}

Table II presents the results of the analysis for disease activity, morning pain, pain during daily activities, as well as pain at night in both patient groups, before and after rehabilitation.

After rehabilitation the DAS28 value improved in both groups: in the CR group it was $4.4 \pm 0.7$ at baseline and $3.8 \pm 0.8$ after treatment ( $p=0.0003$ ), while in the CT group it was $4.0 \pm 0.9$ and $3.3 \pm 0.9(p=0.0001)$, before and after the treatment, respectively. One of the main problems reported was pain, which was assessed using the VAS. Pain intensity in the morning, during daily ac- tivities and at night decreased after treatment in both patient groups, as shown in Table II, and no statistically significant differences were observed between them.

\section{Markers of systemic inflammation}

The ESR and CRP concentrations as markers of inflammation as mentioned above were analyzed in groups, and the results are shown in Table III.

In the CR group, the baseline ESR value was $19.4 \pm 13.2$ and it did not change after therapy $18.9 \pm 11.8(p=0.727)$. Similar results were obtained in the $\mathrm{CT}$ group, where ESR values were $18.5 \pm 16.2$ and $16.7 \pm 15.0(p=0.235)$ before and after rehabilitation, respectively.

No significant differences were found either before or after rehabilitation or between the $\mathrm{CT}$ and CR groups. In the CR group, the concentrations of CRP did not change after rehabilitation, and its initial and post treatment values were $8.9 \pm 8.7$ and $10.6 \pm 11.5(p=0.935)$, respectively. By contrast, in the examined CT group the CRP concentrations decreased significantly after the completion of rehabilitation and its values were 10.6 \pm 9.0 before and $8.7 \pm 7.5$ after the treatment $(p=0.010)$.

\section{Circulating cytokine levels}

The concentrations of tested cytokines in the patients' sera are shown in Table IV. There were no signifi-

Table II. Evaluation of DAS28 and VAS parameters in the patient groups before and after rehabilitation

\begin{tabular}{|c|c|c|c|c|c|c|c|}
\hline \multicolumn{2}{|c|}{ Parameters } & \multicolumn{3}{|c|}{ Rehabilitation group (CR) } & \multicolumn{3}{|c|}{ Cryotherapy group (CT) } \\
\hline & & Before & After & $p$ & Before & After & $p$ \\
\hline \multirow[t]{2}{*}{ DAS28 } & $\begin{array}{c}\text { Mean } \pm \text { SD } \\
\text { Median } \\
\text { (Min; Max) }\end{array}$ & $\begin{array}{c}4.4 \pm 0.7 \\
4.5 \\
(2.9 ; 5.4)\end{array}$ & $\begin{array}{c}3.8 \pm 0.8 \\
3.9 \\
(2.3 ; 5.2)\end{array}$ & 0.0003 & $\begin{array}{c}4.0 \pm 0.9 \\
4.1 \\
(2.3 ; 6.0)\end{array}$ & $\begin{array}{c}3.3 \pm 0.9 \\
3.5 \\
(2.0 ; 4.8)\end{array}$ & 0.0001 \\
\hline & & \multicolumn{2}{|c|}{$\begin{array}{c}p \\
\text { Control vs. Cryotherapy }\end{array}$} & & \multicolumn{2}{|c|}{$\begin{array}{l}\text { Before } \\
\text { After }\end{array}$} & $\begin{array}{l}0.077 \\
0.099\end{array}$ \\
\hline \multirow[t]{2}{*}{$\begin{array}{l}\text { Pain } M \\
\text { (VAS) }\end{array}$} & $\begin{array}{c}\text { Mean } \pm \text { SD } \\
\text { Median } \\
\text { (Min; Max) }\end{array}$ & $\begin{array}{c}4.6 \pm 2.0 \\
4.5 \\
(1 ; 9)\end{array}$ & $\begin{array}{c}3.4 \pm 1.9 \\
3 \\
8)\end{array}$ & 0.00004 & $\begin{array}{c}5.2 \pm 2.2 \\
5 \\
(1 ; 9)\end{array}$ & $\begin{array}{c}3.3 \pm 2.2 \\
3 \\
(0 ; 9)\end{array}$ & 0.0001 \\
\hline & & \multicolumn{2}{|c|}{$\begin{array}{c}p \\
\text { Control vs. cryotherapy }\end{array}$} & & \multicolumn{2}{|c|}{$\begin{array}{l}\text { Before } \\
\text { After }\end{array}$} & $\begin{array}{l}0.345 \\
0.728\end{array}$ \\
\hline \multirow[t]{2}{*}{$\begin{array}{l}\text { Pain } \\
\text { ADL } \\
\text { (VAS) }\end{array}$} & $\begin{array}{c}\text { Mean } \pm \text { SD } \\
\text { Median } \\
(\text { Min; Max })\end{array}$ & $\begin{array}{c}5.0 \pm 2.5 \\
4 \\
(0 ; 9)\end{array}$ & $\begin{array}{c}3.4 \pm 2.2 \\
3 \\
9)\end{array}$ & 0.002 & $\begin{array}{c}4.7 \pm 2.1 \\
4 \\
(0 ; 9)\end{array}$ & $\begin{array}{c}2.9 \pm 2.0 \\
2 \\
(0 ; 7)\end{array}$ & 0.0003 \\
\hline & & \multicolumn{2}{|c|}{$\begin{array}{c}p \\
\text { Control vs. cryotherapy }\end{array}$} & & \multicolumn{2}{|c|}{$\begin{array}{l}\text { Before } \\
\text { After }\end{array}$} & $\begin{array}{l}0.893 \\
0.464\end{array}$ \\
\hline \multirow[t]{2}{*}{$\begin{array}{l}\text { Pain N } \\
\text { (VAS) }\end{array}$} & $\begin{array}{c}\text { Mean } \pm \text { SD } \\
\text { Median } \\
(\text { Min; Max })\end{array}$ & $\begin{array}{c}4.3 \pm 2.8 \\
4 \\
(0 ; 9)\end{array}$ & $\begin{array}{c}3.1 \pm 2.3 \\
3 \\
(0 ; 8)\end{array}$ & 0.001 & $\begin{array}{c}4.4 \pm 2.8 \\
4 \\
(0 ; 9) \\
\end{array}$ & $\begin{array}{c}2.3 \pm 1.9 \\
2 \\
(0 ; 7)\end{array}$ & 0.0001 \\
\hline & & Controlv & erapy & & \multicolumn{2}{|c|}{$\begin{array}{l}\text { Before } \\
\text { After }\end{array}$} & $\begin{array}{l}0.758 \\
0.263\end{array}$ \\
\hline
\end{tabular}

DAS28 - disease activity score, VAS - visual analogue scale, pain M - morning pain, pain ADL - activities of daily living, pain N-night pain 
Table III. Evaluation of markers of systemic inflammation in the patient groups before and after rehabilitation

\begin{tabular}{|c|c|c|c|c|c|c|c|}
\hline \multicolumn{2}{|c|}{ Parameters } & \multicolumn{3}{|c|}{ Rehabilitation group (CR) } & \multicolumn{3}{|c|}{ Cryotherapy group (CT) } \\
\hline & & Before & After & $p$ & Before & After & $p$ \\
\hline \multirow[t]{2}{*}{$\begin{array}{l}\mathrm{ESR} \\
(\mathrm{mm} / \mathrm{h})\end{array}$} & $\begin{array}{c}\text { Mean } \pm \text { SD } \\
\text { Median } \\
\text { (Min; Max) }\end{array}$ & $\begin{array}{c}19.4 \pm 13.2 \\
13 \\
(7 ; 64)\end{array}$ & $\begin{array}{c}18.9 \pm 11.8 \\
14 \\
(6 ; 54)\end{array}$ & 0.727 & $\begin{array}{c}18.5 \pm 16.2 \\
13 \\
(4 ; 76)\end{array}$ & $\begin{array}{c}16.7 \pm 15.0 \\
14 \\
(3 ; 76)\end{array}$ & 0.235 \\
\hline & \multicolumn{4}{|c|}{$\begin{array}{c}p \\
\text { Control vs. cryotherapy }\end{array}$} & \multicolumn{2}{|c|}{$\begin{array}{l}\text { Before } \\
\text { After }\end{array}$} & $\begin{array}{l}0.365 \\
0.280\end{array}$ \\
\hline \multirow[t]{2}{*}{$\begin{array}{l}\text { CRP } \\
(\mathrm{mg} / \mathrm{l})\end{array}$} & $\begin{array}{c}\text { Mean } \pm \text { SD } \\
\text { Median } \\
\text { (Min; Max) }\end{array}$ & $\begin{array}{c}8.9 \pm 8.7 \\
6 \\
(2 ; 41)\end{array}$ & $\begin{array}{c}10.6 \pm 11.5 \\
6 \\
(1 ; 44)\end{array}$ & 0.935 & $\begin{array}{c}10.6 \pm 9.0 \\
8 \\
(1 ; 35)\end{array}$ & $\begin{array}{c}8.7 \pm 7.5 \\
7 \\
(1 ; 28)\end{array}$ & 0.010 \\
\hline & & $\begin{array}{r}p \\
\text { Control vs. cr }\end{array}$ & apy & & \multicolumn{2}{|c|}{$\begin{array}{l}\text { Before } \\
\text { After }\end{array}$} & $\begin{array}{l}0.418 \\
0.848\end{array}$ \\
\hline
\end{tabular}

ESR - erythrocyte sedimentation rate, CRP-C-reactive protein

Table IV. Serum concentrations of cytokines in analyzed patient groups

\begin{tabular}{|c|c|c|c|c|c|c|c|}
\hline \multicolumn{2}{|c|}{ Parameters } & \multicolumn{3}{|c|}{ Rehabilitation group (CR) } & \multicolumn{3}{|c|}{ Cryotherapy group (CT) } \\
\hline & & Before & After & $p$ & Before & After & $p$ \\
\hline \multirow{4}{*}{$\begin{array}{l}\text { IL-6 } \\
\text { (pg/ml) }\end{array}$} & Mean $\pm S D$ & $149 \pm 136$ & $131 \pm 136$ & & $118 \pm 78$ & $121 \pm 76$ & \\
\hline & $\begin{array}{c}\text { Median } \\
\text { (Min; Max) }\end{array}$ & $\begin{array}{c}98 \\
(41 ; 549)\end{array}$ & $\begin{array}{c}85 \\
(44 ; 545)\end{array}$ & 0.570 & $\begin{array}{c}82 \\
(42 ; 332)\end{array}$ & $\begin{array}{c}93 \\
(43 ; 310)\end{array}$ & 0.700 \\
\hline & \multirow{2}{*}{\multicolumn{4}{|c|}{$\begin{array}{c}p \\
\text { Control vs. cryotherapy }\end{array}$}} & \multirow{2}{*}{\multicolumn{2}{|c|}{$\begin{array}{l}\text { Before } \\
\text { After }\end{array}$}} & 0.762 \\
\hline & & & & & & & 0.724 \\
\hline \multirow{4}{*}{$\begin{array}{l}\text { IL-10 } \\
(\mathrm{pg} / \mathrm{ml})\end{array}$} & Average $\pm S D$ & $7.2 \pm 6.5$ & $6.5 \pm 5.3$ & & $6.7 \pm 7.1$ & $6.9 \pm 6.0$ & \\
\hline & $\begin{array}{c}\text { Median } \\
\text { (Min; Max) }\end{array}$ & $\begin{array}{c}5.8 \\
(0.3 ; 21.7)\end{array}$ & $\begin{array}{c}4.8 \\
(0.6 ; 17.7)\end{array}$ & 0.243 & $\begin{array}{c}3.4 \\
(1.0 ; 26.8)\end{array}$ & $\begin{array}{c}6.6 \\
(0.1 ; 18.9)\end{array}$ & 0.809 \\
\hline & \multirow{2}{*}{\multicolumn{4}{|c|}{$\begin{array}{c}p \\
\text { Control vs. cryotherapy }\end{array}$}} & \multirow{2}{*}{\multicolumn{2}{|c|}{$\begin{array}{l}\text { Before } \\
\text { After }\end{array}$}} & 0.665 \\
\hline & & & & & & & 0.931 \\
\hline \multirow{4}{*}{$\begin{array}{l}\text { TNF- } \alpha \\
(\mathrm{pg} / \mathrm{ml})\end{array}$} & Average \pm SD & $25.0 \pm 27.2$ & $26.5 \pm 30.1$ & & $27.2 \pm 18.8$ & $27.8 \pm 20.9$ & \\
\hline & $\begin{array}{l}\text { Median } \\
\text { (Min; Max })\end{array}$ & $\begin{array}{c}15.6 \\
(0.1 ; 81.6)\end{array}$ & $\begin{array}{c}17.2 \\
(0.1 ; 93.0)\end{array}$ & 0.087 & $\begin{array}{c}23.9 \\
(3.1 ; 54.9)\end{array}$ & $\begin{array}{c}24.6 \\
(2.4 ; 67.9)\end{array}$ & 0.427 \\
\hline & \multirow{2}{*}{\multicolumn{4}{|c|}{$\begin{array}{c}p \\
\text { Control vs. cryotherapy }\end{array}$}} & \multirow{2}{*}{\multicolumn{2}{|c|}{$\begin{array}{l}\text { Before } \\
\text { After }\end{array}$}} & 0.555 \\
\hline & & & & & & & 0.650 \\
\hline \multirow{5}{*}{$\begin{array}{l}\text { MIF } \\
(\mathrm{pg} / \mathrm{ml})\end{array}$} & Average $\pm S D$ & $568 \pm 335$ & $458 \pm 290$ & & $492 \pm 157$ & $528 \pm 317$ & \\
\hline & Median & 571 & 423 & 0.447 & 503 & 449 & 0.946 \\
\hline & (Min; Max) & $(91 ; 1507)$ & $(124 ; 1449)$ & & $(118 ; 748)$ & $(112 ; 1333)$ & \\
\hline & \multirow{2}{*}{\multicolumn{4}{|c|}{$\begin{array}{c}p \\
\text { Control vs. Cryotherapy }\end{array}$}} & \multirow{2}{*}{\multicolumn{2}{|c|}{$\begin{array}{c}\text { Before } \\
\text { After }\end{array}$}} & 0.538 \\
\hline & & & & & & & 0.418 \\
\hline
\end{tabular}

$I L$ - interleukin, TNF- $\alpha$-tumor necrosis factor $\alpha$, MIF-macrophage migration inhibitory factor

cant differences between the levels of cytokines before and after rehabilitation.

\section{Discussion}

Rheumatoid arthritis leads to worsening of the functional state, reduction of activity in professional and social life, and thus a reduction in the quality of life. The inflammatory process is associated with abnormal activity of the immune system. The main goal of treating RA patients according to EULAR ACR recommendations is to achieve clinical remission or low disease activity, if remission is unlikely to be achieved within 6 months [17].

Accumulating evidence shows that rehabilitation is one of the elements of treatment that help to improve function and reduce pain in patients with RA. Hirvonen et al. [19] compared the effectiveness of different types of cryotherapy, i.e. $\mathrm{WBC}$ at $-110^{\circ} \mathrm{C}$ and at $-60^{\circ} \mathrm{C}$, cold air local application at $-30^{\circ} \mathrm{C}$ and the use of cold packs locally, in 60 RA patients. The patients received cryotherapy and conventional physiotherapy, as well. Pain decreased in all patient groups, and the best effect 
was observed in the WBC $\left(-110^{\circ} \mathrm{C}\right)$ group. Although DAS slightly decreased, no statistically significant differences between the groups were found. The authors concluded that to achieve pain relief in RA patients, WBC at $-110^{\circ} \mathrm{C}$ is comparable to local cryotherapy and should be considered as a physiotherapy adjunct.

A more extensive systematic review, analyzing 6 publications and involving 257 patients with RA, carried out by Guillot et al. [20], showed that both local and systemic cryotherapy significantly reduce pain, assessed by the VAS, and disease activity (DAS28). Our analysis shows that the monthly cycle of systemic rehabilitation, using both the conventional method and systemic cryotherapy, reduces the activity of RA, assessed on the basis of DAS28. In accordance with the observations of other authors, we also found a significant reduction in pain in both patient groups. Importantly, we noted a significant decrease in the CRP concentration only in the group treated with systemic cryotherapy. Unfortunately, the applied rehabilitation procedures did not significantly affect the circulating concentrations of cytokines, either pro-inflammatory TNF- $\alpha$, IL- 6 and MIF, or anti-inflammatory IL-10, measured in patients' sera at the beginning and end of therapy.

This is in contrast to the results of a study by Jastrząbek et al. [21], conducted in a group of forty RA patients who received 10 days of different local cryotherapies. They assessed two groups of patients, treated with nitrogen vapor at $-160^{\circ} \mathrm{C}$ or with cold airflow at $-30^{\circ} \mathrm{C}$, and observed similar clinical effects in both of them, as the severity of pain, DAS28, and morning stiffness improved significantly in all patients. Moreover, they reported a significant decrease of TNF- $\alpha$ concentrations in sera (nitrogen: $p<0.01$; cold air: $p<0.05$ ), but no change in IL-6 level.

These observations were partly confirmed by Guillot et al. [22] in rats with adjuvant-induced arthritis exposed to local cryotherapy. These authors showed that the treatment with ice was better tolerated and had beneficial effects on arthritis score and joint swelling, while cold gas application induced transient arthritis worsening. In addition, cryotherapy exerted anti-inflammatory local and systemic effects, and upon ice treatment plasma IL-6 concentrations decreased.

However, they observed no effect on TNF- $\alpha$. Recently, Juszczak et al. [23] also reported that WBC significantly reduced subjective pain feeling and morning stiffness duration $(p<0.05)$. Some authors investigated the mechanism(s) of beneficial clinical effects of rehabilitation, but available data are scarce. Exercise with moderate intensity was shown to exert positive effects on the immune system [24].
Interestingly, Sandenberg et al. [25] found that patients who were regularly physically active during 5 years before RA onset had a milder course of the disease, the chance of having DAS28 higher than the median was reduced by $42 \%$, and similar effects were noted for VASpain. There are also published data showing that regular long-term exercise decreases the degree of systemic inflammation in both diseased and healthy populations, and this effect may be associated with changes of IL-6 and TNF expression, regulated by muscle contractions $[26,27]$.

Unfortunately, as discussed above, such a relationship was found only in some but not all studies, including the present work. Correspondingly to our results, Gizińska et al. [28] found that rehabilitation has beneficial effects in RA patients regardless of the method of rehabilitation used.

\section{Limitations of the presented study}

It seems that cryostimulation should be used as a monotherapy to determine whether WBC is more effective than other physiotherapeutic methods. Another limitation is the relatively small size of the studied group.

\section{Conclusions}

In the rehabilitation of RA patients, using physical therapy and kinesiotherapy applied in line with the current needs of the patient and including a minimum of 5 procedures, the observed improvement was the result of comprehensive rehabilitation, regardless of the treatment used. However, the significant decrease of CRP levels after WBC suggests that this type of cryotherapy exerts a beneficial anti-inflammatory effect and is a good method for complementary therapy of pharmacological treatment of RA.

The author declares no conflict of interest.

\section{References}

1. Zimmermann-Górska I. Choroby reumatyczne. Podręcznik dla lekarzy i studentów. Wydawnictwo Lekarskie PZWL, Warszawa 2000.

2. Zimmermann-Górska I. Reumatologia kliniczna. Wydawnictwo Lekarskie PZWL, Warszawa 2008.

3. Criscione LG, St. Clair EW. Tumor necrosis factor-alpha antagonists for the treatment of rheumatic diseases. Curr Opin Rheumatol 2002; 14: 204-211.

4. Kim GW, Lee NR, Pi RH, et al. IL-6 inhibitors for treatment of rheumatoid arthritis: past, present, and future. Arch Pharm Res 2015; 38: 575-584. 
5. Mihara M, Hashizume M, Yoshida $H$, et al. IL-6/IL-6 receptor system and its role in physiological and pathological conditions. Clin Sci (Lond) 2012; 122: 143-159.

6. Kang I, Bucala R. The immunobiology of MIF: function, genetics and prospects for precision medicine. Nat Rev Rheumatol 2019; 15: 427-437.

7. Saxena A, Khosraviani S, Noel S, et al. Interleukin-10 paradox: A potent immunoregulatory cytokine that has been difficult to harness for immunotherapy. Cytokine 2015; 74: 27-34.

8. Tłustochowicz W. Ból w chorobach stawów. Termedia, Poznań 2010.

9. Hagner W. Ręka reumatoidalna. UMK, Bydgoszcz 2006.

10. Seyfried A. Rehabilitacja osób z chorobami reumatologicznymi. In: Dega W, Milanowska K. Rehabilitacja Medyczna. Wydawnictwo Lekarskie PZWL, Warszawa 1994: 402-412.

11. Księżopolska-Orłowska K, Sadura-Sieklucka T, Kasprzak K, et al. The beneficial effects of rehabilitation on hand function in patients with rheumatoid arthritis. Reumatologia 2016; 54: 285-290.

12.Sadura-Sieklucka T. Ręka reumatoidalna. In: KsiężopolskaOrłowska K. Fizjoterapia w reumatologii. Wydawnictwo Lekarskie PZWL, Warszawa 2013: 121-135.

13. Kujawa J, Gworys K. Fizjoterapia w reumatologii. In: Olszewski J. Fizjoterapia w wybranych dziedzinach medycyny. Wydawnictwo Lekarskie PZWL, Warszawa 2013: 290-310.

14. Kądziołka J, Grzegorczyk J, Rawska A. Wpływ fizjoterapii na poziom odczuwanego bólu $u$ chorych na reumatoidalne zapalenie stawów. Prz Med Uniw Rzesz 2009; 1: 46-54.

15. Mika T, Kasprzak W. Fizykoterapia. Wydawnictwo Lekarskie PZWL, Warszawa 2013: 50-53.

16. Księżopolska-Orłowska K, Pacholec A, Jędryka-Góral A, et al. Complex rehabilitation and the clinical condition of working rheumatoid arthritis patients: does cryotherapy always overtop traditional rehabilitation? Disabil Rehabil 2016; 38: 1034 1040.

17. Głuszko P, Filipowicz-Sosnowska A, Tłustochowicz W. Reumatoidalne zapalenie stawów. Reumatologia 2012; 50: 83-90.

18. Wiland P, Madej M, Szmyrka-Kaczmarek M. Reumatoidalne zapalenie stawów. In: Wiland P, Madej M, Szmyrka-Kaczmarek M. Monitorowanie stanu pacjenta w chorobach reumatycznych. Górnicki Wydawnictwo Medyczne, Wrocław 2008: 1-32.
19. Hirvonen HE, Mikkelsson MK, Kautiainen $\mathrm{H}$, et al. Effectiveness of different cryotherapies on pain and disease activity in active rheumatoid arthritis. A randomized single blinded controlled trial. Clin Exp Rheumatol 2006; 24: 295-301.

20. Guillot X, Tordi N, Mourot L, et al. Cryotherapy in inflammatory rheumatic diseases: a systematic review. Expert Rev Clin Immunol 2014; 10: 281-294.

21. Jastrząbek R, Straburzyńska-Lupa A, Rutkowski R, Romanowski W. Effects of different local cryotherapies on systemic levels of TNF- $\alpha$, IL- 6 , and clinical parameters in active rheumatoid arthritis. Rheumatol Int 2013; 33: 2053-2060.

22. Guillot X, Martin H, Seguin-Py S, et al. Local cryotherapy improves adjuvant-induced arthritis through down-regulation of IL-6/IL-17 pathway but independently of TNF $\alpha$. PLoS One 2017; 12: e0178668.

23. Juszczak K, Skotarczak A, Wojtyła-Buciora P, et al. Influence of systemic cryotherapy on quality of life in patients with rheumatoid arthritis. Hygeia Public Health 2018; 53: 193-198.

24. Simpson RJ, Kunz H, Agha N, Graff R. Exercise and the Regulation of Immune Function. Prog Mol Biol Transl Sci 2015; 135 : 355-380.

25. Sandberg ME, Wedrén S, Klareskog L, et al. Patients with regular physical activity before onset of rheumatoid arthritis present with milder disease. Ann Rheum Dis 2014; 73: 1541-1544.

26. Febbraio MA, Pedersen BK. Muscle-derived interleukin-6: mechanisms for activation and possible biological roles. FASEB J 2002; 16: 1335-1347.

27. Petersen AM, Pedersen BK. The anti-inflammatory effect of exercise. J Appl Physiol 2005; 98: 1154-1162.

28. Gizińska M, Rutkowski R, Romanowski W, et al. Effects of Whole-Body Cryotherapy in Comparison with Other Physical Modalities Used with Kinesitherapy in Rheumatoid Arthritis. Biomed Res Int 2015; 2015: 409174. 